\title{
Role of MicroRNA Molecules in Colon Cancer Etiology
}

\section{Farid E Ahmed ${ }^{*}$}

GEM Tox Labs, Institute for esearch in Biotechnology, 2607 Calvin Way, Greenville, NC 27834, USA

*Corresponding author: Farid E Ahmed, PhD, Director, GEM Tox Labs Institute for Research in Biotechnology, 2607 Calvin Way, Greenville, NC 27834, USA, Tel: +1 2523217261; Fax: +1 2527561656; E-mail: instresbiotech@yahoo.com

Received date: March 10, 2014; Accepted date: April 21, 2014; Published date: April 29, 2014

Copyright: $\odot$ Ahmed FE et al. This is an open-access article distributed under the terms of the Creative Commons Attribution License, which permits unrestricted use, distribution, and reproduction in any medium, provided the original author and source are credited.

\begin{abstract}
The biogenesis of micro (mi) RNA suggests that nearly 3\% of human genes are encoded for micro (mi) RNAs, and computer predictions indicate that more than $30 \%$ of protein coding genes in humans are coded by miRNAs through an imperfect binding to the 3' untranslated region (UTR) of target messenger (m) RNA affecting gene silencing and leading to either transcription repression, or induction of messenger (m) RNA degradation. The expression of several miRNAs in noninvasive body fluids/excrements has been linked to development of colorectal cancer (CRC) and its progression. The majority of miRNA genes are oriented antisense to neighboring genes, and miRNA genes are transcribed by polymerases II and III. The rate of evolution of miRNAs has been very slow, which has permitted morphological innovation by making gene expression specific, a process that permitted the genesis of complex organisms. Bacteria lack true miRNAs. Bioinformatics approaches to predict putative miRNA target genes has been facilitated by finding that miRNA target recognition is partly based on simple sequence complementarity, and exact base pairing between miRNAs and their targets is required only in the first six to eight bases from the $5^{\prime}$ end of the miRNA.
\end{abstract}

Keywords: Gene expression; Histopathology; Metastasis; Risk factors; Staging

\section{Introduction}

CRC is the 2nd and 3rd most common malignancy worldwide in men and women, respectively, in developing and developed countries, including USA and Europe, with an estimated one million new cases and half million deaths yearly $[1,2]$. In USA, CRC represents $10 \%$ of incident cancers and cancer deaths. About $6 \%$ of the population will develop CRC in their lifetime. In 2009, 102,900 new cases and 51,370 deaths were estimated [3,4] (Table 1). Globally, there are about 1 million new cases and about 500,000 deaths/year, and these numbers are destined to dramatically increase because of worldwide adoption of a Western-type diet, i.e., diet rich in calories, carbohydrates and fats, and poor in essential nutrients, vitamins and minerals [5,6]. Although CRC incidence has declined from about 60 per 100,000 in 1975 to $~ 50$ per 100,000 in 2004 , and the decrease in USA mortality has recently accelerated, it has changed little for African American men and women [7-9] (Table 2). Moreover, data show that early-onset carcinomas ( $<40$ years) have increased during the past four decades and pathologic features became more biologically aggressive $[10,11]$. Five-year survival rates for CRC are strikingly different by stage, ranging from $90 \%$ for localized-disease to $10 \%$ for distant-disease (www.cdc.gov), clearly arguing for an early detection for this cancer. In spite of the billions of dollars spent in the USA over the last three decades, there is currently no validated reliable sensitive or specific biomarker for CRC screening [12].

\begin{tabular}{|c|c|c|c|c|c|c|c|}
\hline $\begin{array}{l}\text { Test } \\
\text { Specification }\end{array}$ & $\begin{array}{l}\text { FBOT• } \\
\text { Guaiac Immunologic }\end{array}$ & $\begin{array}{l}\text { Methylated gene } \\
\& \quad \text { chromosomal } \\
\text { loci }\end{array}$ & $\begin{array}{l}\text { Promoter } \\
\text { methylation }\end{array}$ & $\begin{array}{l}\text { Mutated } \\
\text { DNA } \\
\text { markers }\end{array}$ & $\begin{array}{l}\text { Colonoscopy } \\
\text { examination } \Delta\end{array}$ & $\begin{array}{l}\text { Proteomic } \\
\text { Approach }\end{array}$ & $\begin{array}{l}\text { mRNA miRNA } \\
\text { Approch.Approach } \boldsymbol{\nabla}\end{array}$ \\
\hline Noninvasive & Yes Yes & Yes & Yes & Yes & No & Yes & Yes Yes \\
\hline Sensitivity & $10.8 \% \dagger 16.3 \% \dagger$ & $87.5 \%$ & $31 \% \dagger$ & $18.2 \%$ & $87 \%$ & $75 \%$ & $>80 \%>90 \% \boldsymbol{\Psi}$, \\
\hline Specificity & $95 \% 94.5 \%$ & $82 \%$ & $95 \%$ & 94.4 & $100 \%$ & $>95 \%$ & $>95 \%>95 \% \pi$ \\
\hline Automation & No No & No & No & No & No & Yes & Yes Yes \\
\hline Cost & $\$ 15 \delta \$ 25 \delta$ & $\$ 400 \delta$ & $\$ 150 \delta$ & $\$ 695 \delta$ & $\$ 900 \delta$ & $\$ 650 \delta$ & $\$ 250 \delta \$ 100 \delta$ \\
\hline
\end{tabular}

Table 1: Comparison of tests employed for premalignant $\dagger$ and malignant human colon cancer screening. $\dagger$ For polyps $\geq 1 \mathrm{~cm}$ in diameter, villous or tubuvillous, or the presence of high grade dysplasia, $\bullet$, from refs $13,22,44$, - Only for advanced cancer, but not adenoma, based on vimentin gene, DY loci 5p21 and OC91199, from refs 39, 40; Based on one gene, from ref. 37; - aFrom refs 36, 38, 41, 42; $\boldsymbol{\Delta}$ From refs. 23, 24, 222, 223; - From refs 42, 224; Based on our data, ref. 35; $\mathbf{\nabla}$ Based on our miRNA data, ref. 25, gpreliminary miRNA results are based on a limited 
number of genes and a small sample size; SEstimates are based on contacts with other test developers, and our experience. with assay requirements and developments.

\begin{tabular}{|l|l|l|l|l|l|l|}
\hline \multicolumn{2}{|l|}{ Estimated New Cases $^{* *}$} & \multicolumn{3}{l|}{ Estimated Deaths $^{* * *}$} \\
\hline Cancer & $\begin{array}{l}\text { Both } \\
\text { Sexes }\end{array}$ & Males & Females & $\begin{array}{l}\text { Both } \\
\text { Sexes }\end{array}$ & Males & Females \\
\hline Colon & 102900 & 49,470 & 53,430 & 51,370 & 26,580 & 24,790 \\
\hline Rectum & 40,870 & 23,580 & 17,290 & $\uparrow$ & $\uparrow$ & $\uparrow$ \\
\hline
\end{tabular}

\section{Public health implications}

Mortality and morbidity from CRC represent a major health problem involving a malignant disease that is theoretically preventable through screening. Early detection would be greatly enhanced if accurate, practical and cost effective diagnostic biomarkers for this malignancy were available. Current screening methods lack sensitivity (e.g., fecal occult blood test, FOBT) [17-19], costly and have low compliance, or could result in mortality (e.g., colonoscopy) [20,21].

Table 2: Estimated New Cancer Cases \& Deaths by Sex due to CRC in the USA in $2009^{\star}$ Source: American Cancer Society (www.cancer.org).

The traditional understanding of the evolution of CRC was based on a model emphasizing progression from an adenoma to a carcinoma stage through genetic alterations involving tumor suppressor genes [13]. An alternative pathway has been the serrated one, which involves hyperplastic polyps or related lesions; however, our understanding of this newer model is currently incomplete [14].

\section{Differences between colon and rectal cancer}

Epidemiologic evidence suggests that colon cancers (CCs) and rectal cancers (RCs) differ in their morbidities and etiologies. RC is more common in Asia (China) where it accounts for over 50\% of CRC, compared with $<30 \%$ in Western countries [15]. In contrast, CC was shown to account for over $60 \%$ of CRC cases in the USA and Europe, is related mostly to environmental factors (e.g., consumption of fatty foods and less exercise) and to a Caucasian ethnic origin [16-19], all are factors which collectively suggest differences in carcinogenesis between CC and RC. Moreover, several structural and molecular studies have also indicated differences in etiology, clinical manifestation, pathological features and genetic abnormalities between CC and RC [20-22].

Studies using molecular biology assays have found that tumor suppressor genes, point mutations and genetic instability due to epigenetic components differ according to the subsite colorectum. CC has been reported to more likely have $\mathrm{CpG}$ island methylator phenotype and k-ras mutations, whereas rectal and distal colon tumors are more likely to have p53 and APC mutations [23-26]. Gene hybridization techniques have shown amplification of $20 \mathrm{q}$ in CC, compared with amplification of $12 p$ in RC [27]. Another study indicated significant differences between rectal and colon cancer in the amplification of genes for cell cycle such as cyclin-A2, -B1, -D1 and -E [28]. An omic study using Illumina HT-12 V4.0 Expression Bead chip oligonucleotide microarrays (San Diego, CA) found RC to be more complex than CC as 676 genes related to 11 signal pathways were differentially expressed in CC development, compared to 1,789 genes related to 30 signal pathways altered in RC, with 824 common differentially expressed genes up- or down-regulated in both CC and RC [15] all are facts that have collectively lead to the conclusion that colon and rectal cancers represent two distinct types of tumors. In this review, we have focused on colon cancer because it is more prevalent in the USA. Our data and others [22 -34] have shown that quantitative changes in the expression of few miRNA genes in tissue, stool or plasma that are associated with colon cancer would permit development of more sensitive and specific CRC molecular markers than those currently available on the market for a cancer that is deadly if not diagnosed before metastasis. Using stable molecules such as miRNAs that is not easily degradable when extracted from stool or blood and manipulated thereafter, a miRNA -approach is preferable to a transcriptomic mRNA-, mutation DNA-, epigenetic- or a proteomic-based test [35-44]. If performance criteria are met in a validated undertaking, the non-invasive miRNA-based test in a noninvasive medium such as stool, or a semi-invasive medium human blood plasma based on high throughput automated technologies and quantitative expression measurements, commonly used in the diagnostic clinical laboratory, would be advanced to the clinical setting and will make a significant impact on the preventive oncology of CRC. Table 3 presents a comparison of tests that are currently in use, or those under development for CRC screening, compared to a proposed test using miRNAs after further development and validation of this test.

\begin{tabular}{|c|c|c|c|c|c|c|c|c|}
\hline \multirow{2}{*}{$\begin{array}{l}\text { Race/ } \\
\text { Ethnicity }\end{array}$} & \multicolumn{4}{|l|}{ Men } & \multicolumn{4}{|c|}{ Women } \\
\hline & $\begin{array}{l}\text { Loc } \\
\text { al }\end{array}$ & $\begin{array}{l}\text { Region } \\
\text { al }\end{array}$ & $\begin{array}{l}\text { Dista } \\
\text { nt }\end{array}$ & $\begin{array}{l}\text { Unstag } \\
\text { ed }\end{array}$ & $\begin{array}{l}\text { Loc } \\
\text { al }\end{array}$ & $\begin{array}{l}\text { Region } \\
\text { al }\end{array}$ & $\begin{array}{l}\text { Dista } \\
\text { nt }\end{array}$ & $\begin{array}{l}\text { unstag } \\
\text { ed }\end{array}$ \\
\hline $\begin{array}{l}\text { Non-Hispanic } \\
\text { White }\end{array}$ & 42 & 35 & 19 & 4 & 40 & 36 & 19 & 5 \\
\hline $\begin{array}{l}\text { Non-Hispanic } \\
\text { African } \\
\text { American }\end{array}$ & 36 & 34 & 25 & 5 & 36 & 34 & 24 & 6 \\
\hline $\begin{array}{l}\text { Asian } \\
\text { American/ } \\
\text { Pacific } \\
\text { Islander }\end{array}$ & 40 & 37 & 19 & 4 & 38 & 41 & 18 & 3 \\
\hline $\begin{array}{l}\text { American } \\
\text { Indian/Alaska } \\
\text { Native }\end{array}$ & 36 & 37 & 24 & 3 & 40 & 39 & 17 & 3 \\
\hline Hispanic & 37 & 36 & 22 & 5 & 37 & 36 & 21 & 5 \\
\hline
\end{tabular}

Table 3: Colorectal Cancer Stage Distribution (\%) by Race/Ethnicity, 1999-2006 Source: Reference (5) Alekruse S, Kosary C, Krapcho M et al. eds (2010) SEER Cancer Statistics Review 1975-2007, http:// seer.cancer.gov/csr/1975-2007/, based on November 2009 SEER data submission, posted on the SSR web site, April 2010, Bethesda, MD, NCI. 


\section{MiRNs discovery, nomenclature, biogenesis, function and evolution}

MiRNAs are small RNA molecules that regulate gene expression post-transcriptionally. The first miRNA was discovered in 1993 by Victor Ambros, Rosalind Lee and Rhonda Feinbaum while working on genes involved in developmental timing in the millimeter-long roundworm Caenorhabditis elegans $[45,46]$. One of the genes, termed lin-4, did not encode a protein, but instead a novel 22-nucleotide small RNA. Seven years later (year 2000), Reinhart and his colleagues discovered a second 22-nucleotide small RNA of the same type, let-7, which repressed lin-41, lin-14, lin-28, lin-42 and def-12 expression during developmental stage transition in $C$. elegans timing [47]. Homologs of let-7 gene were identified in other animals, including humans [48]. The conservation of let-7 across species suggested an important biological role for this small RNA and pointed out to the existence of a wider phenomenon. At that time, the mechanism of RNA interference (RNAi) linking miRNA and RNAi pathways and showing that both mechanisms share common components was discovered. In the following year, more than 100 additional small regulatory RNAs resembling lin-4, and let-7, now named miRNAs, were identified in worms, the fruit fly and humans [49-51]. Subsequently many more miRNAs were also identified in DNA viruses [52], algae [53], and almost all multicellular organisms such as flowering plants, worms, flies, fish, frogs and mammals [54,55]. Computer predictions of miRNA targets suggest that $~ 30 \%$ of human protein-coding genes are regulated by miRNAs [56,57]. These discoveries culminated in 2007 to the award of the Nobel Prize in Physiology and Medicine to Andrew Fire and Craig Mello. Today, more than 1000 human miRNAs have been experimentally identified. Computer predictions of miRNA targets suggest that about $3 \%$ of human genes encode for miRNAs, and in excess of $30 \%$ of human protein coding genes are regulated by miRNAs [58], through imperfectly binding to the 3' untranslated region (UTR) of target mRNAs resulting in prevention of protein accumulation by either transcription repression, or by inducing mRNA degradation, making miRNAs as one of the most abundant classes of regulatory genes in humans.

MiRNAs are sequentially processed from longer precursor molecules that are encoded by the miRA genes [59]. A miRNA gene is written as prefix (mir) to distinguish it from the corresponding mature miRNA (called miR) followed by a dash and a number (e.g., mir-1 verus miR-1) to indicate the order of naming. MiRNAs with nearly identical sequences except for one or two nucleotides are annotated with an additional lower case. For example, miR-123a would be closely related to miR-123b. Pre-miRNAs that lead to $100 \%$ identical mature miRNAs but that are located at different places in the genomes are indicated with an additional dash-number suffix. For example, the pre-miRNA has-mir-194-1 and has-mir-194-2 lead to an identical mature miRNA (has-miR-194) but are located at different regions of the genome. Species of origin is designated with a three-liter prefix, e.g., has-miR-123 is a human (Homo sapiens) miRNA and oarmiR-123 is a sheep (Ovis aries) miRNA. Other common prefixes include "V" for a miRNA encoded by a viral genome, and " $d$ " for the fruit fly Drosophila. When two mature miRNAs originate from opposite arms of the same pre-miRNA, they are denoted with a $-3 p$ (sense) or $-5 p$ (antisense) suffix. When relative expression levels are known, an asterisk following the name indicates a miRNA expressed at low levels relative to the miRNA in the opposite arm of the hairpin. For example, miR-123 and miR-123* would share pre-miRNA, but more miR-123 would be found in the cell [60].
The majority of characterized miRNA genes are intergenic (or oriented antisense to neighboring genes) and are therefore suspect to be transcribed as independent units [61]. On the other hand, a miRNA gene could be transcribed with its host gene, providing a mean for coupled regulation of miRNA and protein-coding gene [62]. As much as $40 \%$ of miRNA genes may lie in the introns of protein and nonprotein coding genes, or even in exons of long nonprotein-coding transcripts, which are usually found -although not exclusively-in the same orientation, and are thus often regulated together with their host genes [63]. Other miRNA genes showing a common promoter include the $42-48 \%$ of all miRNAs originating from polycistronic units containing multiple discrete loops from which mature miRNAs are processed [64], although this does not imply that the mature miRNAs of a family will be homologous in structure and function. These promoters have similarities in their motifs to promoters of other genes transcribed by RNA polymerase II such as protein coding genes [65]. Six percent of human miRNAs show RNA editing (IsomiRs), the sitespecific modification of RNA sequences, to yield products different from those encoded by this DNA, which increases the diversity and scope of miRNA action beyond that implicated from the genome alone.

MiRNA genes are usually transcribed by RNA polymerase II (Pol II) [64]. The polymerase often binds to a promoter found near the DNA sequence encoding what will become the hairpin loop of the premiRNA. The resulting transcript is capped with a specially modified nucleotide at the 5' end, polyadenylated with multiple adenosines a poly (A) tail, [66] and spliced. Animal miRNAs are initially transcribed as part of one arm of an $\sim 80$ nucleotide RNA stem-loop that in turn forms part of a several hundred nucleotides long miRNA precursor termed a primary miRNA (pri-miRNA). When a stem-loop precursor is found in the 3' UTR, a transcript may serve as a primiRNA and an mRNA [67]. RNA polymerase III (Pol III) transcribes some miRNAs, especially those with upstream Alu sequences transfer RNAs (tRNAs), and mammalian wide interspersed repeat (MWIR) promoter units. A single pri-miRNA may contain from one to six miRNA precursors. These hairpin loop structures are composed of about 70 nucleotides each. Each hairpin is flanked by sequences necessary for efficient processing.

The double-stranded RNA structure of the hairpins in a pri-miRNA is recognized by a nuclear protein known as DiGeorge Syndrome Critical Region 8 (DGCR8), named so for its association with DiGeorge Syndrome. DGCR8 associates with the enzyme Drosha, which cuts RNA to form the "Microprocessor" complex [68]. In this complex, DGCR8 orients the catalytic RNase III domain of Drosha to liberate hairpins from pri-miRNAs by cleaving RNA about eleven nucleotides from the hairpin base (two helical RNA turns into the stem). The product resulting has a two-nucleotide overhang at its 3' end : it has $3^{\prime}$ hydroxyl and $5^{\prime}$ phosphate groups. It is often termed precursor-miRNA (pre-miRNA). Pre-miRNAs that are spliced directly out of introns, bypassing the Microprocessor complex, are known as "mitrons". Although originally thought to exist only in Drosophila and C. elegans, mirtrons are now found in mammals [69]. Perhaps as many as $16 \%$ of pri-miRNAs may be altered through nuclear RNA editing [70]. RNA editing can halt nuclear processing (for example, of pri-miR-142), leading to degradation by the ribonuclease Tudor-SN and alter downstream processes including cytoplasmic miRNA processing and target specificity (e.g., by changing the seed region of miR-376 in the central nervous system) [71]. Pre-miRNA hairpins are exported from the nucleus in a process involving the nucleocytoplasmic shuttle Exportin 5 a member of the 
Page 4 of 12

karyopherin family, which recognizes a two-nucleotide overhang left by the RNase III enzyme Drosha at the 3 ' end of the pre-miRNA. Exportin-5-mediated transport to the cytoplasm is energy-dependent, using GTP bound to the Ran protein [72]. In cytoplasm, the premiRNA hairpin is cleaved by the RNase III enzyme Dicer, yielding an imperfect miRNA:miRNA* duplex about 22 nucleotides long. Overall hairpin length and loop size influence the efficiency of Dicer processing, and the imperfect nature of the miRNA:miRNA* pairing also affects cleavage. Although either strand of the duplex may potentially act as a functional miRNA, only one strand is usually incorporated into the RNA-induced silencing complex (RISC) where the miRNA and its mRNA target interact.

Two ribonuclease enzymes, Drosha and Dicer, process the primary transcript (pri-miRNA) to generate the mature miRNAs. The primary transcripts contain one or more double-stranded stem-loop RNA structures of $\sim 70$ nucleotide sequence bases that can fold back on itself to form a double helix with a region of imperfect base pairing that forms an open loop at the end (Figure 1). The enzyme Drosha (Pasha in plants) excises the stem-loop structure to form the precursor miRNA (pre-miRNA) [71]. After export into the cytoplasm, the premiRNA is cleaved by the ribonuclease Dicer to form a short RNA duplex [72]. Following untwisting one RNA strand becomes the mature single-stranded miRNA, while the complementary strand (called miRNA ${ }^{\star}$ ) is rapidly degraded (Figure 2 ). MiRNAs recognize their targets based on sequence complementarity in which a mature miRNA is partially complementary to one or more mRNAs [73]. In humans, the complementary sites are normally within the 3'untranslated region of target mRNA. The mature miRNA forms a complex with proteins known as RNA-induced silencing complex (RISC). The miRNA incorporated into the silencing complex binds to target mRNA by base pairing, a process that causes inhibition of protein translation and/or degradation of mRNA [74] (Figure 3), leading to inhibition of protein translation of target genes, whereas mRNA levels are infrequently degraded or cleaved [59] by imperfectly binding to the 3' UTR of target mRNAs resulting in prevention of protein accumulation by either transcription repression, or by inducing mRNA degradation. Each miRNA generally targets hundreds of conserved mRNAs and several hundreds of nonconserved targets that operate in a complex regulatory network, and it is predicted that miRNAs together regulate thousands of human genes, as well as regulating protein expression.

RISC is also known as a miRNA ribonucleoprotein complex (miRNP); RISC with incorporated miRNA is sometimes referred to as "miRISC. Dicer processing of the pre-miRNA is thought to be coupled with unwinding of the duplex. Generally, only one strand is incorporated into the miRISC, selected on the basis of its thermodynamic instability and weaker base-pairing relative to the other strand [74]. The position of the stem-loop may also influence strand choice [75]. The other strand, called the passenger strand due to its lower levels in the steady state, is denoted with an asterisk $\left(^{*}\right)$ and is normally degraded. In some cases, both strands of the duplex are viable and become functional miRNA that target different mRNA populations' strand $[72,76]$.

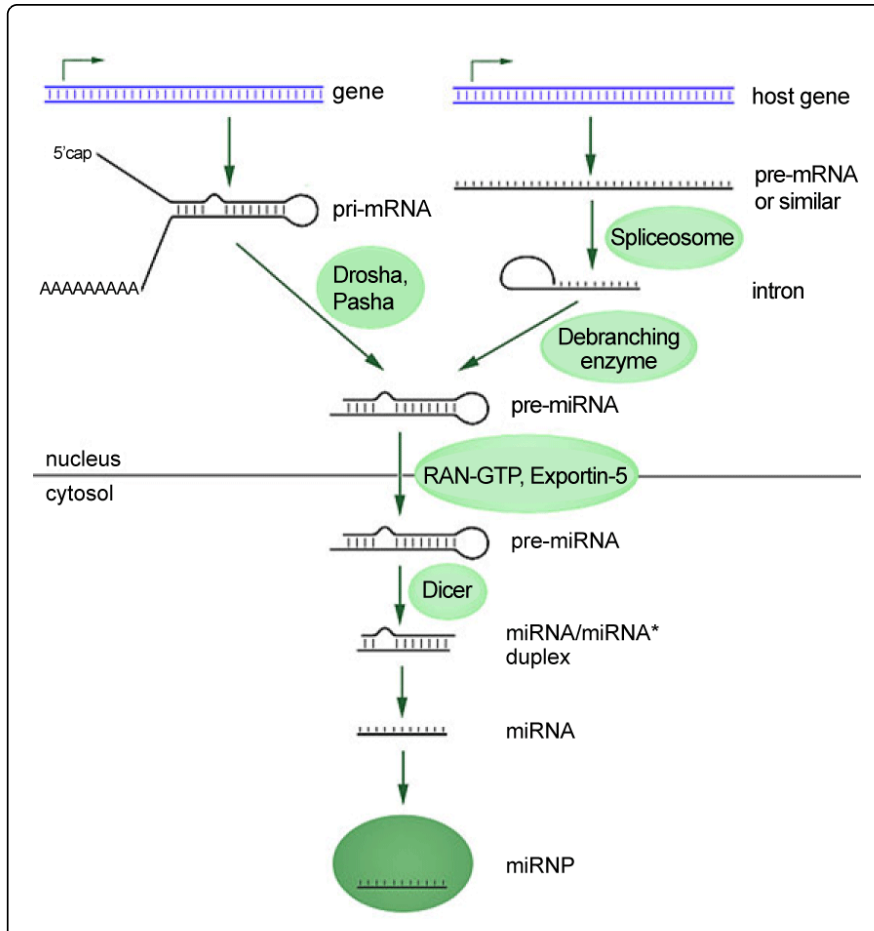

Figure 1: Biogenesis of miRNA molecules in the nucleus and cytoplasm of cells.

RISC is also known as a miRNA ribonucleoprotein complex (miRNP); RISC with incorporated miRNA is sometimes referred to as "miRISC. Dicer processing of the pre-miRNA is thought to be coupled with unwinding of the duplex. Generally, only one strand is incorporated into the miRISC, selected on the basis of its thermodynamic instability and weaker base-pairing relative to the other strand [74]. The position of the stem-loop may also influence strand choice [75]. The other strand, called the passenger strand due to its lower levels in the steady state, is denoted with an asterisk $\left(^{*}\right)$ and is normally degraded. In some cases, both strands of the duplex are viable and become functional miRNA that target different mRNA populations' strand $[72,76]$.

Members of the Argonaute (Ago) protein family are central to RISC function. Argonautes are needed for miRNA-induced silencing and contain two conserved RNA binding domains: a PAZ domain that can bind the single stranded 3' end of the mature miRNA and a PIWI domain that structurally resembles ribonuclease- $\mathrm{H}$ and functions to interact with the 5 ' end of the guide strand. They bind the mature miRNA and orient it for interaction with a target mRNA. Some argonautes, for example human Ago2, cleave target transcripts directly; argonautes may also recruit additional proteins to achieve translational repression [77]. The human genome encodes eight Argonaut proteins divided by sequence similarities into two families: AGO (with four members present in all mammalian cells and called E1F2C/hAgo in humans), and PIWI (found in the germ line and hematopoietic stem cells) strand [77,78]. 
Page 5 of 12

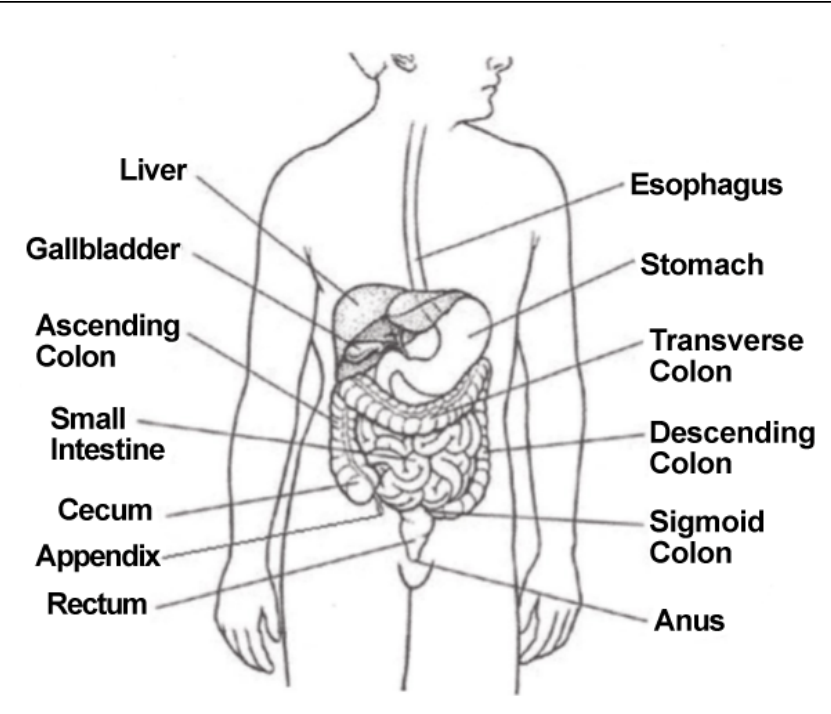

Figure 2: Schematic illustration depicting the digestive or gastrointestinal [GI] system.

Additional RISC components include TRBP (human immunodeficiency virus) (HIV) trans activating response RNA (TAR) binding protein, protein activator of the interferon induced protein kinase (PACT), the SMN complex, fragile $\mathrm{X}$ mental retardation protein (FMRP), Tudor staphylococcal nuclease-domain-containing protein (Tudor-SN), the putative DNA helicase MOV10, and the RNA recognition motif containing protein TNRC6B [78]. Gene silencing may occur either via mRNA degradation or preventing mRNA from being translated. If there is complete complementation between the miRNA and target mRNA sequence, Ago2 can cleave the mRNA and lead to direct mRNA degradation. Yet, if there isn't complete complementation, the silencing is achieved by preventing translation [76,79].

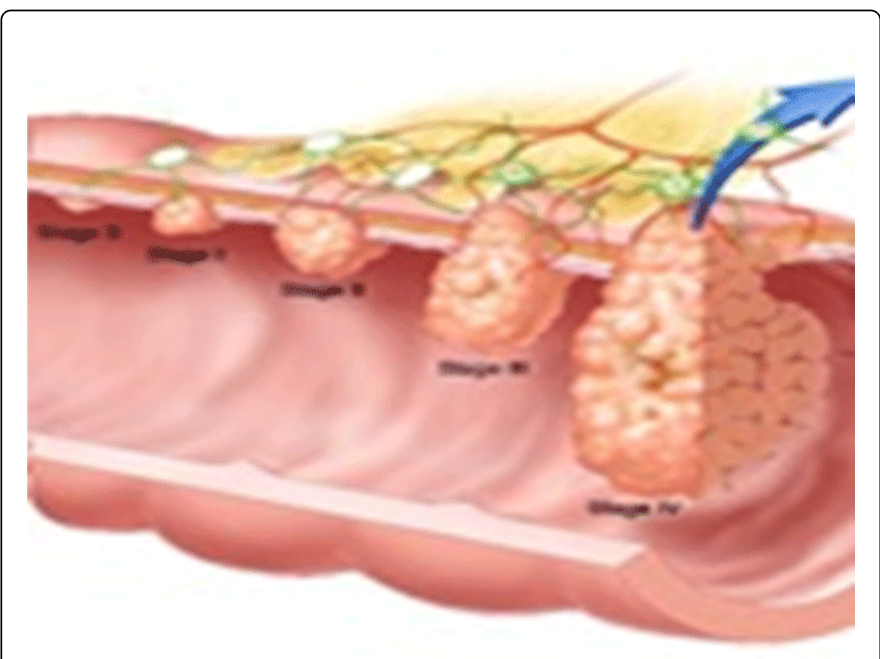

Figure 3: Schematic depiction of the five TNM stages of colon cancer.

Turnover of mature miRNA is needed for rapid changes in miRNA expression profiles. During miRNA maturation in the cytoplasm, uptake by the Argonaute protein is thought to stabilize the guide strand, while the opposite ( ${ }^{\star}$ or "passenger") strand is preferentially destroyed. In what has been called a "use it or lose it" strategy, Argonaute may preferentially retain miRNAs with many targets over miRNAs with few or no targets, leading to degradation of the nontargeting molecules [80]. Decay of mature miRNAs in C. elegans is mediated by the $5^{\prime}$-to- $3^{\prime}$ exoribonuclease XRN2 [81]. In plants, SDN (small RNA degrading nuclease) family members degrade miRNAs in the opposite $\left(3^{\prime}\right.$-to- $\left.5^{\prime}\right)$ direction. Similar enzymes are encoded in animal genomes, but their roles have not yet been elucidated [82].

Several miRNA modifications affect miRNA stability. Uridylation of some animal miRNAs has been reported and both plant and animal miRNAs may be altered by addition of adenine (A) residues to the $3^{\prime}$ end of the miRNA. An extra A added to the end of mammalian miR-122, a liver-enriched miRNA important in Hepatitis C, stabilizes the molecule, and plant miRNAs ending with an adenine residue have slower decay rates [80].

The function of miRNAs in the cells appears to be gene regulation. For that purpose, a miRNA is complementary to a part of one or more mRNAs. Animal miRNAs are usually complementary to a site in the 3'-UTR, whereas plant miRNAs are usually complementary to coding regions of mRNAs. Perfect or near perfect base pairing with the target RNA promotes cleavage of the RNA, as often occurs in plant miRNAs, whereas animals miRNAs more often have only partly the right sequence of nucleotides to bond with the target mRNA [83]. The match-ups are imperfect. For partially complementary microRNAs to recognize their targets, nucleotides 2-7 of the miRNA (its 'seed region) still have to be perfectly complementary. Animal miRNAs inhibit protein translation of the target mRNA [84]. MiRNAs that are partially complementary to a target can also speed up deadenylation causing mRNAs to be degraded sooner [85]. While degradation of miRNAtargeted mRNA is well documented, whether or not translational repression is accomplished through mRNA degradation, translational inhibition, or a combination of the two is hotly debated. Recent work on miR-430 has shown that translational repression is caused by the disruption of translation initiation, independent of mRNA deadenylation [86]. MiRNAs occasionally also cause histone modification and DNA methylation of promoter sites, affecting the expression of target genes [87].

Nine mechanisms of miRNA action are discerned using a unified mathematical model: a) cap-40S initiation inhibition, b) $60 \mathrm{~S}$ ribosomal unit joining inhibition, c) elongation inhibition, d) ribosome drop-off (premature termination), e) cotranslational nascent protein degradation, f) sequestration in P-bodies, g) mRNA decay (destabilization), h) mRNA cleavage, and i) transcriptional inhibition through miRNA-mediated chromatin reorganization followed by gene silencing (Figure 4). It is often impossible to discern these mechanisms using the experimental data about stationary reaction rates nevertheless; they are differentiated by dynamics and have different kinetic signatures [88].

Unlike plant miRNAs, the animal miRNAs target a diverse set of genes [89]. However, genes involved in functions common to all cells, such as gene expression, have relatively fewer miRNA target sites and seem to be under selection to avoid targeting by microRNAs [90]. Double strands (ds) RNA can also activate gene expression, a mechanism that has been termed "small RNA-induced gene activation" or "RNAa dsRNAs". Targeting gene promoters can induce potent transcriptional activation of associated genes. This was demonstrated in human cells using synthetic dsRNAs termed small activating RNAs 
Page 6 of 12

(SaRNAs) [91], as well as for endogenous microRNA [92]. Interactions between miRNAs and complementary sequences on genes and pseudogenes that share sequence homology are thought to be a back channel of communication regulating expression levels between paralogous genes. Given the name "competing endogenous RNAs (ceRNAs), these miRNAs bind to miRNA response elements on genes and pseudogenes, providing another explanation for the persistence of non-coding DNA [93].

MiRNAs are considered significant phylogenetic markers because of their very low rate of evolution [94]. Their origin may have permitted the development of morphological innovation, and by making gene expression more specific and fine-tunable, this could have permitted the genesis of complex organs [95] and ultimately complex life [96]. Indeed, rapid bursts of morphological innovation have generally been associated with a high rate of miRNA accumulation [94,95]. MiRNAs originate predominantly by the random formation of hairpins in non-coding sections of DNA (i.e. introns or intergene regions), and also by duplication and modification of existing miRNAs [97].

The rate of evolution (i.e. nucleotide substitution) in recently originated miRNAs is comparable to that elsewhere in the non-coding DNA, implying evolution by neutral drift; however, older miRNAs have a much lower rate of change (often less than one substitution per hundred million years) [95], suggesting that once a miRNA gains a function it undergoes extreme purifying selection [97]. At this point, a miRNA is rarely lost from an animal's genome, although miRNAs which are more recently derived (and thus presumably nonfunctional) are frequently lost $[5,95]$. This makes them a valuable phylogenetic marker and a possible solution to such outstanding phylogenetic problems as the relationships of arthropods [98]. MiRNAs feature in the genomes of most eukaryotic organisms, from the brown algae [99] to the animals. Latest miRBase release (v20, June 2013), http://mirbase.org contains 24521 microRNA loci from 206 species, processed to produce 30424 mature microRNA products [100]. Whilst short RNA sequences (50 - hundreds of base pairs) of a broadly comparable function occur in bacteria, bacteria lack true miRNAs [101].

\section{Role of MiRNAs in Cancer and Biomarker Development}

Three observations in the early history of miRNAs suggest a potential role in human cancer: a) the earliest miRNAs discovered in C. elegans and the Drosophila were found to control cell proliferation and apoptosis [102,103], implying that their deregulation could contribute to proliferative diseases such as cancer, b) many miRNA genes were located at fragile sites, as well as minimal regions of loss of heterozygosity, or amplification of common breakpoint regions in the genome, suggesting their involvement in carcinogenesis [104], and c) malignant tumors and tumor cell lines were found to have widespread deregulated miRNA expression compared to normal tissues $[105,106]$. An unanswered question is whether the altered miRNA expression observed in cancer is a cause or a consequence of malignant transformation?

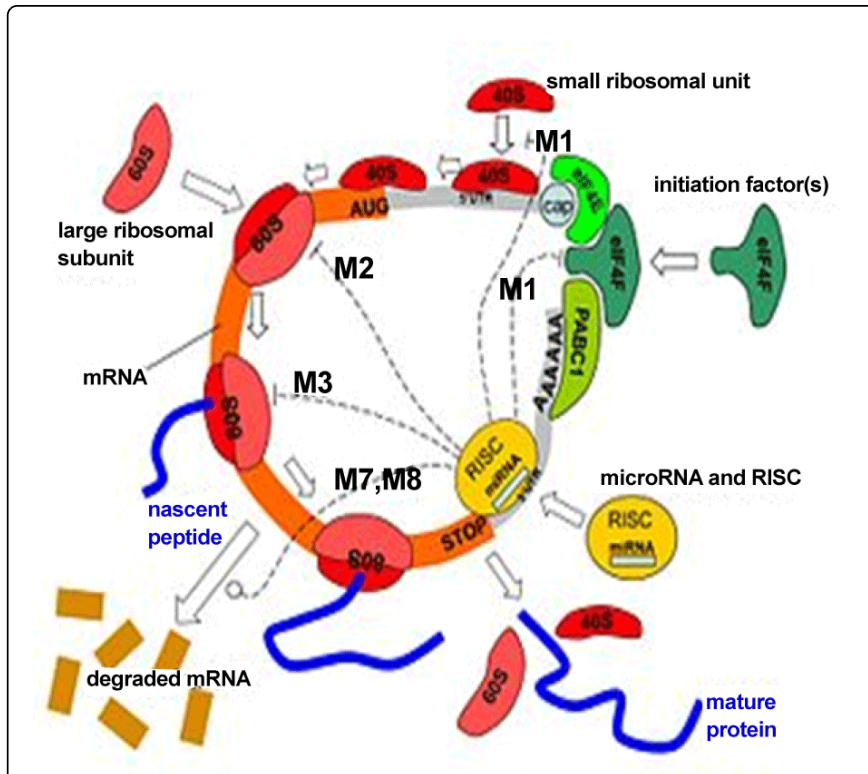

Figure 4: Nine mechanisms of translation repression are shown: M1) on the initiation process, preventing assembling of the initiation complex or recruiting the $40 \mathrm{~S}$ ribosomal subunit; M2) on the ribosome assembly; M3) on the translation process; M7 and M8) on the degradation of mRNA. There exist other mechanisms of miRNA action on protein translation (transcriptional, transport to P-bodies, ribosome drop-off, co-translational protein degradation and others) that are not visualized here. The 40S and $60 \mathrm{~S}$ are light and heavy components of the ribosome, $80 \mathrm{~S}$ is the assembled ribosome bound to mRNA, eIF4F is a translation initiation factor, PABC1 is the Poly-A binding protein, and "cap" is the mRNA cap structure needed for mRNA circularization (which can be the normal m7G-cap or artificial modified A-cap). The initiation of mRNA can proceed in a cap-independent manner, through recruiting $4540 \mathrm{~S}$ to IRES (Internal Ribosome Entry Site) located in 5'UTR region. The actual work of RNA silencing is performed by the RISC in which the main catalytic subunit is one of the AGO, and miRNA serves as a template for recognizing specific mRNA sequences.

Deletion on chromosome 13, which is the most frequent chromosomal abnormality in chronic lymphocytic leukemia (CLL), had been suspected for long to contribute to leukemogenesis, although studies had failed to identify a causal gene. Calin and his colleagues. observed that the expression two miRNA genes, mir-15 and mir-16, located within this $30-\mathrm{kb}$ deletion in blood samples from patients with chronic lymphocytic leukemia (CLL) were shown to be absent or down regulated in $68 \%$ of cases compared to normal tissue or lymphocytes [107], suggesting that the two miRNAs were causally involved in the pathogenesis of CLL. Three reports provided the first mechanistic insight into how $\mathrm{mi}$ RNAs might contribute to carcinogenesis in 2005. Two independent studies described the relationship between a miRNA cluster, mir-17-91, and the Myc oncogenic pathway $[108,109]$, and a third report showed an interaction between let-7 miRNA and the RAS proto-oncogene [110].

In mammals, miRNAs play key roles in diverse biological processes, including embryogenesis and stem cell maintenance [111,112], hematopoietic cell differentiation [113], development [47,114] and 
apoptosis [115], and specific miRNAs are critical in oncogenesis [116], effective in classifying solid [117,118] and liquid tumors [107,113], and serve as oncogenes or suppressor genes $[108,119]$. MiRNAs have great promise serving as biomarkers for cancer diagnosis, prognosis and/or response to therapy $[22-24,106]$. MiRNA expression has been found to be deregulated in a wide range of human diseases, including cancer [116]. Profiles of miRNA expression differ between normal tissues and tumor types, and evidence suggests that miRNA expression profiles can cluster similar tumor types together more accurately than expression profiles of protein-coding mRNA genes [22,24,30]. However, it is uncertain whether altered miRNA expression is a cause or a consequence of pathological processes. A study on the role of miRNA and gene expression identified miRNAs that classify molecular cancer subtypes [120]. Although the natural mechanisms for the dysregulation of miRNAs is still largely unknown, one theory tested in colon cancers proposes that DNA hypermethylation leads to down-regulation of certain miRNAs [121].

A global decrease in miRNA levels has been observed in human cancers, indicating these molecules may have an intrinsic function in tumor suppression. Lu et al. [30] in an analysis of 217 human and mouse miRNAs across 334 human cancers, cancer cell lines, and normal tissues [30] were the first to show that the expression levels of many miRNAs were significantly reduced in cancers compared to the corresponding normal tissues. Cancers had significantly reduced global miRNA expression. Poorly differentiated tumors had lower miRNA levels compared with more-differentiated tumors, which lead to the hypothesis that miRNAs functions to drive terminal differentiation and prevent cell division. Global changes in miRNA expression may reflect the degree of cell differentiation [30]. A study that investigated the expression of 241 human miRNAs in NCI-60 panel of human cancer cell lines and in normal tissues confirmed that most miRNAs were expressed at lower levels in human tumor-derived cell lines compared with the corresponding normal tissue [112].

Until recently, it was uncertain whether the altered miRNA expression observed in cancer was a cause or consequence of malignant transformation. Kumar et al. [119] proved for the first time that widespread reduction in miRNA expression promotes carcinogenesis. Global reduction in the production of mature miRNAs through a knockdown of the enzymes Drosha and Dicer in mouse and human cancer cell lines showed a decreased steady-state miRNA level, which was correlated with an enhanced cellular growth in vitro. These cells generated faster growing and more invasive tumors compared to controls upon injection into nude mice. To assess the effect of global miRNA loss in vivo, the authors deleted the miRNA-processing enzyme Dicer in a mouse model of lung cancer, and showed that these mice had an increased tumor burden, correlated with an increase in tumor number and size, as well as the presence of tumors tumors which were less well differentiated when compared to controls. The study also demonstrated that loss of miRNAs leads to upregulation of proto-oncogenes RAS and c-Myc, although it remains unknown whether loss of all miRNAs is necessary or whether reduction of a subgroup of key tumor is required for tumorigenesis [118].

Transcriptional networks are often deregulated in cancer and may lead to altered transcription of miRNA genes. A study showed that miR-34 is regulated by the p53 transcription factor [115]. The p53 protein, known as the guardian of the genome, regulates the cellular response to stress and cancer, initiating DNA damage. He and colleagues [120] found that miR-34 is directly activated by transcription factor p53 after DNA damage. Expression of miR-34 induces cell cycle arrest and thereby acts together with other effectors of the p53 tumor suppressor network to inhibit cell proliferation. An independent group showed an upregulation of miR-34 by p53 upon DNA damage, which promoted apoptosis [115]. These data indicate that altered expression of miRNAs is not simply a secondary event that reflects the less differentiated state of cancer cells, but at least, in some cases, miRNA expression is specifically driven by oncogenes and tumor suppressor genes.

Transcriptional networks may drive miRNA expression in cancers. Studies by Ma et al. [121] suggested a model by which a pleiotropic transcription factor, Twist, induces expression of miR-10b, which suppresses its direct target and in turn activates a pro-metastatic gene, leading to tumor cell invasion and metastasis in mouse and human breast cancer cells. Moreover, the expression level of miR-10b in primary human breast carcinomas correlated with clinical progression, suggesting that specific miRNAs have a role beyond the tumorinitiation and could directly participate in tumor progression and metastasis.

The transcription of mir-124a gene was shown to be inactivated by hypermethylation of its promoter in various human tumors. Epigenetic silencing is a well-known mechanism to inactivate proteincoding genes in cancer cells and could similarly inactivate miRNAs. MiR-127 was found to be highly induced in cultured human cancer cells after treatment with demethylating drugs, suggesting its subjugation to epigenetic silencing through promoter hypermethylation [122].

Two independent groups showed that disrupting the interaction of a single miRNA and its target can produce an abnormal phenotype in mammalian cells. Mayr et al. [123] and Lee and Dutta [124] demonstrated that miRNA function could be regulated through loss of miRNA binding sites in the target gene through chromosomal translocations in a high mobility group A2 (Hmga2) oncogene, leading to loss of the let-7 miRNA binding sites in its mRNA. Disrupted repression of Hmga2 by let-7 was shown to promote oncogenic transformation and growth in mammalian cells. Moreover, evidence suggests that miRNAs are regulated indirectly through control of their processing enzymes. Thomson et al. [125] showed that a down regulation of miRNAs in human cancer was not associated with reduced levels of the primary miRNA transcripts, suggesting that regulation of miRNAs could occur during subsequent processing steps, e.g., through altered function of the enzyme Drosha.

Cancers of epithelial and hematopoietic origin show distinct miRNA profiles. A subgroup of gastrointestinal tumors, which arise from endoderm, was distinguished by their miRNA expression patterns. Moreover, tumors within a single cell lineage such as acute lymphoblastic leukemia were further differentiated according to their underlying genetic abnormality into BCR/ABL-positive tumors, T-cell tumors, and those with MLL gene rearrangement. When a miRNA expression profile of 217 miRNAs established to an independent series of 17 poorly differentiated tumors of unknown origin was applied, a correct diagnosis was established in 12 out of 17 of the tumors. On the other hand, transcriptomic gene expression profiling based on 16,000 mRNAs did not accurately classify the tumors [30]. This finding has an important clinical implication because if miRNAs prove useful for clinical diagnosis, their advantage lies in the stability of these molecules compared to easily fragmented mRNAs. Besides, miRNAs are long-lived in vivo [126] and very stable in vitro [127], which might allow analysis of paraffin-embedded samples for routine diagnostic applications. 


\section{Conclusions}

Many researchers had long thought that miRNAs played a role in cancer development and progression. In the late 1990s and early 2000, the focus was on stool colonocytes. But in 2008, some investigators noticed that miRNAs could also be detected in the blood, possibly paving the way for their use as cancer biomarkers in a semi-invasive medium [128]. The expression of a number of miRNAs has been linked to different cancers and their progression. But contrary to the stool, the origins of these miRNAs and how they arrive in the blood are not yet fully known [129], Still, miRNAs as biomarkers of cancer are being validated and are winding their way toward the clinic.

MiRNAs are interesting biomarkers that are functionally important, play a significant role in gene regulation, are amplifiable, and are stable molecules. Moreover, miRNA expression profiles allow for distinguishing malignant and non-malignant tissue, as well as distinguishing different tumor entities, and measuring miRNA molecules provides a lot of information content [130]. There is also a small number of miRNAs, about 1000 validated miRNAs, which gives a global picture of a given tumor, compared to, for example, hundreds of thousands of messenger RNAs. Furthermore, because they are nucleic acids, there are a number of extant tools that can be used to analyze miRNAs, like for example microarrays and PCR techniques. Most circulating miRNAs are associated with Argonaute2, which is part of the RISC silencing complex. But whether these circulating miRNAs come from normal tissue or tumor tissue and how they are released into body fluids - through cell death or some other process - are mostly unanswered questions. It is possible that cell death could cause miRNAs to be released into the blood or other body fluids, or the cells might selectively release miRNAs in vesicles or exosomes. In healthy tissue, there is evidence that cells release miRNAs, both in vesicles and in protein complexes. Those miRNAs can then act as intercellular signaling molecules. If they are taken up by a recipient cell, they could possibly modulate gene expression of that recipient cell. Tumor tissue cells may act similarly as they could release miRNAs that promotes a microenvironment that helps the tumor to survive, giving tumors a selective advantage. Work is needed to determine how or what the balance is between passive release by various ways and release that is programmed within the cell. Host cells, like immune cells, might also be sources of miRNAs in cancer patient. Many circulating miRNAs linked to solid tumors are also expressed in blood cells [24]. It often does not matter where miRNAs come from, as long as they are well-validated markers.

A novel miRNA-profiling based screening assay for the detection of early-stage CRC has been developed and is currently in clinical trials. Early results showed that blood plasma samples collected from patients with early, resectable (Stage II) colorectal cancer could be distinguished from those of sex-and age-matched healthy volunteers. Sufficient selectivity and specificity could be achieved using small (less than $1 \mathrm{~mL}$ ) samples of blood. The test has potential to be a costeffective, non-invasive way to identify at-risk patients who should undergo colonoscopy [131].

A number of sophisticated bioinformatics approaches are being developed to predict putative miRNA target genes based on the fact that miRNA target recognition is at least partly based on simple sequence complementarity [132-135]. This has been facilitated by the finding that exact base pairing between miRNAs and their targets commonly appears to be required only in the first six to eight bases from the $5^{\prime}$ end of the miRNA. The short nature of the seed region allows a single miRNA to act on up to a hundred different target sites, and all human miRNAs together may regulate up to one third of protein coding genes $[80,135]$, suggesting suggests a highly complex network of miRNA-target interactions. Another approach to discovering miRNA target genes is to knock out or overexpress a particular miRNA and use conventional microarrays to identify genes that show changes in expression. This approach is based on the observation that some miRNAs can also downregulate mRNA levels in addition to down regulating protein levels of their target genes [136]. An experimental validation of miRNA target sites has been to express a miRNA in vivo while simultaneously expressing and monitoring the target mRNA linked to a reporter gene, i.e., Luciferase [134,137-144].

\section{Recommendations}

Most studies carried out for diagnosing the role miRNAs in cancer employed small numbers of subjects. Although there are fewer miRNA than mRNA genes, we and others $[140,141]$ are in the opinion that diagnostic studies employing large numbers of subjects (in the hundreds of individuals) are needed to evaluate potential application of miRNA in early detection and diagnosis of colon cancer [142], whereas for analysis of transcriptomic mRNA expressions, the number of subjects needed will be at least in the thousand because there are much more transcripts than miRNAs. When working with body fluids such as plasma, a challenge is to establish standardized protocols for extracting and quantifying circulating miRNAs. However, thus far it has been difficult to do so as the technology keeps changing and improving; however, it is expected that in 5 to 10 years, scientists carrying out this work will have worked out the best way to quantitate miRNAs in blood and also in other body fluids/excrements.

An additional approach towards data integration aimed at the identification of conserved changes to reduce background noise in expression profiling studies, and subsequently in miRNA studies, is represented by cross-species comparison of tumors from human patients and animal models of cancer [143]. This approach is expected to pinpoint genes of conserved functional relevance in the process of tumor formation and progression in mammalian intestinal tumorigenesis. Although mice mainly develop small intestinal tumors [144-147], comparison with human may be useful in further reducing the noise generated by organ-specific genes. Other animals such as pigs, which resemble humans more than rodents, can be used, but these studies cannot employ large numbers of pigs because of cost.

\section{Key Issues}

CoIon and rectal cancers are two different diseases as shown by differences in epidemiology, ethnic origin, embryologic differences, and different responses to molecular tests.

It is important to develop cost-effective markers for the early diagnosis of this disease in order to enhance screening and decrease disease mortality.

Risk factors for colon cancer include factors that cannot be changed such as age, history of IBDs, diabetes, and life-style factors such as diet, physical inactivity, smoking and alcohol consumption.

The genetic heterogeneity in colon cancer is increased by the influence of mismatch DNA repair.

MiRNA genes are usually transcribed by RNA polymerase II, and some with Polmerase III, especially those with upstream Alo sequences, transfer RNAs and mammalian wide interspersed promoter units. 
Because of their low rate of evolution, miRNAs are significant phylogenetic markers, making gene expression specific, which allowed for the genesis of complex organs, and subsequently complex life.

Bioinformatics approaches are developed to predict putative miRNA target genes, as miRNA target recognition is partly based on simple sequence complementarity and the finding that exact base pairing between miRNAs and their targets is required only in the first six to eight bases from the $5^{\prime}$ end of the miRNA.

There are 24521 microRNA loci from 206 species, processed to produce 30424 mature microRNA products in miRBase, release (v20), in June 2013.

MiRNA molecules are expressed in colon cancer tissue, as well as from stool and blood taken from human subjects, although the expression in the later non-invasive and semi-invasive media is less than in tissue.

MiRNA molecules can serve as sensitive and specific biomarkers for the early noninvasive diagnosis of colon cancer, more economically and conveniently than any other test on the market. However, a large, well designed epidemiologic study that employs large numbers of subject will be needed to validate results.

\section{Acknowledgements}

I express my gratitude to Paul W. Vos, Clark D. Jeffries and Gerard J. Nuovo and for stimulating discussions. I also thank NIH/NCI Program Director Patricia Weber, and NIH/NCI Grant Management Administrator, Sy L. Shackleford, and express our appreciation to Trudy Guffey and John W. Hardin from North Carolina Office of Science and technology, Raleigh, NC, USA. for facilitating our interaction with the respective funding agencies during this work. This work has been supported by NIH Grant 1R43-CA144823-A1-01 from the Department of Health and Human Services, National Cancer Institute, National Institutes of Health, Bethesda, Maryland, USA.; the State of North Carolina SBIR/STTR Matching Funds Program, Grant \# G30433001211SBIR from North Carolina Office of Science and technology, Raleigh, NC, USA.; and additional operating funds from GEM Tox Labs, Institute for Research in Biotechnology, Greenville, North Carolina, USA.

\section{References}

1. Jemal A, Siegel R, Ward E, Murray T, Xu J, et al. (2007) Cancer statistics, 2007. CA Cancer J Clin 57: 43-66.

2. Alekruse S, Kosary C, Krapcho M, et al. (2010) eds. SEER Cancer Statistics Review 1975-2007, based on November 2009 SEER data submission, posted on the SSR web site, April 2010, Bethesda, MD, NCI, 2010.

3. Edwards BK, Ward E, Kohler BA, Eheman C, Zauber AG, et al. (2010) Annual report to the nation on the status of cancer, 1975-2006, featuring colorectal cancer trends and impact of interventions (risk factors, screening, and treatment) to reduce future rates. Cancer 116: 544-573.

4. Kohler BA, Ward E, McCarthy BJ, Schymura MJ, Ries LA, et al. (2011) Annual report to the nation on the status of cancer, 1975-2007, featuring tumors of the brain and other nervous system. J Natl Cancer Inst 103: 714-736.

5. Ahmed FE (2006) Gene-gene, gene-environment \& multiple interactions in colorectal cancer. J Environ Sci Health C Environ Carcinog Ecotoxicol Rev 24: 1-101.

6. Ahmed FE (2009) Cancer. In Nutrition and Exercise Concerns of Middle Age. Ed. J. Driskell, CRC Taylor \& Francis, Boca Raton, FL, USA.
7. Irby K, Anderson WF, Henson DE, Devesa SS (2006) Emerging and widening colorectal carcinoma disparities between Blacks and Whites in the United States (1975-2002). Cancer Epidemiol Biomarkers Prev 15: 792-797.

8. Ward E, Jemal A, Cokkinides V, Singh GK, Cardinez C, et al. (2004) Cancer disparities by race/ethnicity and socioeconomic status. CA Cancer J Clin 54: 78-93.

9. Du XL, Fang S, Vernon SW, El-Serag H, Shih YT, et al. (2007) Racial disparities and socioeconomic status in association with survival in a large population-based cohort of elderly patients with colon cancer. Cancer 110: 660-669.

10. Peterson NB, Murff HJ, Ness RM, Dittus RS (2007) Colorectal cancer screening among men and women in the United States. J Womens Health (Larchmt) 16: 57-65.

11. Yantiss RK, Goodarzi M, Zhou XK, Rennert H, Pirog EC, et al. (2009) Clinical, pathologic, and molecular features of early-onset colorectal carcinoma. Am J Surg Pathol 33: 572-582.

12. Smith RA, Cokkinides V, Brawley OW (2009) Cancer screening in the United States, 2009: a review of current American Cancer Society guidelines and issues in cancer screening. CA Cancer J Clin 59: 27-41.

13. Kinzler KW, Vogelstein B (1996) Lessons from hereditary colorectal cancer. Cell 87: 159-170.

14. East JE, Saunders BP, Jass JR (2008) Sporadic and syndromic hyperplastic polyps and serrated adenomas of the colon: classification, molecular genetics, natural history, and clinical management. Gastroenterol Clin N Am 37: 25-46.

15. Li JN, Zhao L, Wu J, Wu B, Yang H, et al. (2012) Differences in gene expression profiles and carcinogenesis pathways between colon and rectal cancer. J Dig Dis 13: 24-32.

16. Davies RJ, Miller R, Coleman N (2005) Colorectal cancer screening: prospects for molecular stool analysis. Nat Rev Cancer 5: 199-209.

17. Peterson NB, Murff HJ, Ness RM, Dittus RS (2007) Colorectal cancer screening among men and women in the United States. J Womens Health (Larchmt) 16: 57-65.

18. Centers for Disease Control and Prevention. Increased use of colorectal cancer test: United States, 2002 and 2004, MMWR Mortal Wkly 55: 208-311, 2006.

19. Morikawa T, Kato J, Yamaji Y, Wada R, Mitsushima T, et al. (2005) A comparison of the immunochemical fecal occult blood test and total colonoscopy in the asymptomatic population. Gastroenterology 129: 422-428.

20. Bressler B, Paszat LF, Vinden C, Li C, He J, et al. (2004) Colonoscopic miss rates for right-sided colon cancer: a population-based analysis. Gastroenterology 127: 452-456.

21. Gatto NM, Frucht H, Sundararajan V, Jacobson JS, Grann VR, et al. (2003) Risk of perforation after colonoscopy and sigmoidoscopy: a population-based study. J Natl Cancer Inst 95: 230-236.

22. Ahmed FE, Jeffries CD, Vos PW, Flake G, Nuovo GJ, et al. (2009) Diagnostic microRNA markers for screening sporadic human colon cancer and active ulcerative colitis in stool and tissue. Cancer Genomics Proteomics 6: 281-295.

23. Ahmed FE, Vos PW, Clark J et al. (2009) Differences in mRNA and microRNA expression profiles in human colon adenocarcinoma HT-29 cells treated with either intensity-modulated radiation therapy (IMRT), or conventional radiation therapy (RT). Cancer Genom. Proteom. 6: 109-127.

24. Ahmed FE, Amed NC, Vos PW, Bonnerup C, Atkins JN, et al. (2012) Diagnostic microRNA markers to screen for sporadic human colon cancer in blood. Cancer Genomics Proteomics 9: 179-192.

25. Minoo P, Zlobec I, Peterson M, Terracciano L, Lugli A (2010) Characterization of rectal, proximal and distal colon cancers based on clinicopathological, molecular and protein profiles. Int J Oncol 37: 707-718. 
Page 10 of 12

26. Slattery ML, Curtin K, Wolff RK, Boucher KM, Sweeney C, et al. (2009) A comparison of colon and rectal somatic DNA alterations. Dis Colon Rectum 52: 1304-1311.

27. He QJ, Zeng WF, Sham JS, Xie D, Yang XW, et al. (2003) Recurrent genetic alterations in 26 colorectal carcinomas and 21 adenomas from Chinese patients. Cancer Genet Cytogenet 144: 112-118.

28. Aamodt R, Jonsdottir K, Andersen SN, Bondi J, Bukholm G, et al. (2009) Differences in protein expression and gene amplification of cyclins between colon and rectal adenocarcinomas. Gastroenterol Res Pract 2009: 285830

29. Ng EK, Chong WW, Jin H, Lam EK, Shin VY, et al. (2009) Differential expression of microRNAs in plasma of patients with colorectal cancer: a potential marker for colorectal cancer screening. Gut 58: 1375-1381.

30. Lu J, Getz G, Miska EA, Alvarez-Saavedra E, Lamb J, et al. (2005) MicroRNA expression profiles classify human cancers. Nature 435: 834-838.

31. Mitchell PS, Parkin RK, Kroh EM, Fritz BR, Wyman SK, et al. (2008) Circulating microRNAs as stable blood-based markers for cancer detection. Proc Natl Acad Sci U S A 105: 10513-10518.

32. Chen X, Ba Y, Ma L, Cai X, Yin Y, et al. (2008) Characterization of microRNAs in serum: a novel class of biomarkers for diagnosis of cancer and other diseases. Cell Res 18: 997-1006.

33. Michael MZ, O' Connor SM, van Holst Pellekaan NG, Young GP, James RJ (2003) Reduced accumulation of specific microRNAs in colorectal neoplasia. Mol Cancer Res 1: 882-891.

34. Slaby O, Svoboda M, Fabian P, Smerdova T, Knoflickova D, et al. (2007) Altered expression of miR-21, miR-31, miR-143 and miR-145 is related to clinicopathologic features of colorectal cancer. Oncology 72: 397-402.

35. Ahmed FE, Vos P, iJames S, Lysle DT, Allison RR, et al. (2007) Transcriptomic molecular markers for screening human colon cancer in stool and tissue. Cancer Genomics Proteomics 4: 1-20.

36. Ahmed FE, Vos PW, Ijames S, Lysle DT, Flake G, et al. (2007) Standardization for transcriptomic molecular markers to screen human colon cancer. Cancer Genomics Proteomics 4: 419-431.

37. Itzkowitz SH, Jandorf L, Brand R, Rabeneck L, Schroy PC 3rd, et al. (2007) Improved fecal DNA test for colorectal cancer screening. Clin Gastroenterol Hepatol 5: 111-117.

38. Lenhard K, Bommer GT, Asutay S, Schauer R, Brabletz T, et al. (2005) Analysis of promoter methylation in stool: a novel method for the detection of colorectal cancer. Clin Gastroenterol Hepatol 3: 142-149.

39. Ahlquist DA, Skoletsky JE, Boynton KA, Harrington JJ, Mahoney DW, et al. (2000) Colorectal cancer screening by detection of altered human DNA in stool: feasibility of a multitarget assay panel. Gastroenterology 119: 1219-1227.

40. Lees NP, Harrison KL, Hall CN, Margison GP, Povey AC (2007) Human colorectal mucosal O6-alkylguanine DNA-alkyltransferase activity and DNA-N7-methylguanine levels in colorectal adenoma cases and matched referents. Gut 56: 380-384.

41. Huang ZH, Li LH, Yang F, Wang JF (2007) Detection of aberrant methylation in fecal DNA as a molecular screening tool for colorectal cancer and precancerous lesions. World J Gastroenterol 13: 950-954.

42. Traverso G, Shuber A, Levin B, Johnson C, Olsson L, et al. (2002) Detection of APC mutations in fecal DNA from patients with colorectal tumors. N Engl J Med 346: 311-320.

43. Imperiale TF, Ransohoff DF, Itzkowitz SH, Turnbull BA, Ross ME; Colorectal Cancer Study Group (2004) Fecal DNA versus fecal occult blood for colorectal-cancer screening in an average-risk population. N Engl J Med 351: 2704-2714.

44. Ahmed FE (2009) Liquid chromatography-mass spectrometry: a tool for proteome analysis and biomarker discovery and validation. Expert Opin Med Diagn 3: 429-444.

45. Lee RC, Feinbaum RL, Ambros V (1993) The C. elegans heterochronic gene lin-4 encodes small RNAs with antisense complementarity to lin-14. Cell 75: 843-854.
46. Fire A, Xu S, Montgomery MK, Kostas SA, Driver SE, et al. (1998) Potent and specific genetic interference by double-stranded RNA in Caenorhabditis elegans. Nature 391: 806-811.

47. Reinhart BJ, Slack FJ, Basson M, Pasquinelli AE, Bettinger JC, et al. (2000) The 21-nucleotide let-7 RNA regulates developmental timing in Caenorhabditis elegans. Nature 403: 901-906.

48. Pasquinelli AE, Reinhart BJ, Slack F, Martindale MQ, Kuroda MI, et al. (2000) Conservation of the sequence and temporal expression of let-7 heterochronic regulatory RNA. Nature 408: 86-89.

49. Lagos-Quintana M, Rauhut R, Lendeckel W, Tuschl T (2001) Identification of novel genes coding for small expressed RNAs. Science 294: 853-858.

50. Lai EC, Tam B, Rubin GM (2005) Pervasive regulation of Drosophila Notch target genes by GY-box-, Brd-box-, and K-box-class microRNAs. Genes Dev 19: 1067-1080.

51. Lau NC, Lim LP, Weinstein EG, Bartel DP (2001) An abundant class of tiny RNAs with probable regulatory roles in Caenorhabditis elegans. Science 294: 858-862.

52. Sullivan CS, Ganem D (2005) MicroRNAs and viral infection. Mol Cell 20:3-7.

53. Pfeffer S, Zavolan M, Grässer FA, Chien M, Russo JJ, et al. (2004) Identification of virus-encoded microRNAs. Science 304: 734-736.

54. Lim LP, Glasner ME, Yekta S, Burge CB, Bartel DP (2003) Vertebrate microRNA genes. Science 299: 1540.

55. Reinhart BJ, Weinstein EG, Rhoades MW, Bartel B, Bartel DP (2002) MicroRNAs in plants. Genes Dev 16: 1616-1626.

56. Komori T, Takemasa I, Yamasaki M, et al (2004). Identification of virusencoded miRNAs. Science 304: 734-736.

57. Lewis BP, Burge CB, Bartel DP (2005) Conserved seed pairing, often flanked by adenosines, indicates that thousands of human genes are microRNA targets. Cell 120: 15-20.

58. Rajewsky N (2006) microRNA target predictions in animals. Nat Genet 38 Suppl: S8-13.

59. Bartel DP (2004) MicroRNAs: genomics, biogenesis, mechanism, and function. Cell 116: 281-297.

60. Bartel DP (2009) MicroRNAs: target recognition and regulatory functions. Cell 136: 215-233.

61. Lau NC, Lim LP, Weinstein EG, Banlel DP (2001) An abundant class of tiny RNA with probable regulatory role in Caenorthabdites elegans. Science 294: 858-862.

62. Mraz M, Dolezalova D, Plevova K, Stano Kozubik K, Mayerova V, et al. (2012) MicroRNA-650 expression is influenced by immunoglobulin gene rearrangement and affects the biology of chronic lymphocytic leukemia. Blood 119: 2110-2113.

63. Kim YK, Kim VN (2004) Processing of intronic microRNA. EMBO J 26: 725-783.

64. Lee Y, Kim M, Han J, Yeom KH, Lee S, et al. (2004) MicroRNA genes are transcribed by RNA polymerase II. EMBO J 23: 4051-4060.

65. Zhou X, Ruan J, Wang G, Zhang W (2007) Characterization and identification of microRNA core promoters in four model species. PLoS Comput Biol 3: e37.

66. Cai X, Hagedorn $\mathrm{CH}$, Cullen BR (2004) Human microRNAs are processed from capped, polyadenylated transcripts that can also function as mRNAs. RNA 10: 1957-1966.

67. Faller M, Guo F (2008) MicroRNA biogenesis: there's more than one way to skin a cat. Biochim Biophys Acta 1779: 663-667.

68. Altuvia Y, Landgraf P, Lithwick G, Elefant N, Pfeffer S, et al. (2005) Clustering and conservation patterns of human microRNAs. Nucleic Acids Res 33: 2697-2706.

69. Berezikov E, Chung WJ, Willis J, Cuppen E, Lai EC (2007) Mammalian mirtron genes. Mol Cell 28: 328-336.

70. Ohman M (2007) A-to-I editing challenger or ally to the microRNA process. Biochimie 89: 1171-1176. 
Page 11 of 12

71. Kawahara Y, Megraw M, Kreider E, Iizasa H, Valente L, et al. (2008) Frequency and fate of microRNA editing in human brain. Nucleic Acids Res 36: 5270-5280.

72. Murchison EP, Hannon GJ (2004) miRNAs on the move: miRNA biogenesis and the RNAi machinery. Curr Opin Cell Biol 16: 223-229.

73. Lund E, Dahlberg JE (2006) Substrate selectivity of exportin 5 and Dicer in the biogenesis of microRNAs. Cold Spring Harb Symp Quant Biol 71: 59-66.

74. Krol J, Sobczak K, Wilczynska U, Drath M, Jasinska A, et al. (2004) Structural features of microRNA (miRNA) precursors and their relevance to miRNA biogenesis and small interfering RNA/short hairpin RNA design. J Biol Chem 279: 42230-42239.

75. Lin SL, Chang D, Ying SY (2005) Asymmetry of intronic pre-miRNA structures in functional RISC assembly. Gene 356: 32-38.

76. Okamura K, Chung WJ, Lai EC (2008) The long and short of inverted repeat genes in animals: microRNAs, mirtrons and hairpin RNAs. Cell Cycle 7: 2840-2845.

77. Pratt AJ, MacRae IJ (2009) The RNA-induced silencing complex: a versatile gene-silencing machine. J Biol Chem 284: 17897-17901.

78. MacRae IJ, Ma E, Zhou M, Robinson CV, Doudna JA (2008) In vitro reconstitution of the human RISC-loading complex. Proc Natl Acad Sci US A 105: 512-517.

79. Lim LP, Lau NC, Garrett-Engele P, Grimson A, Schelter JM, et al. (2005) Microarray analysis shows that some microRNAs downregulate large numbers of target mRNAs. Nature 433: 769-773.

80. Kai ZS, Pasquinelli AE (2010) MicroRNA assassins: factors that regulate the disappearance of miRNAs. Nat Struct Mol Biol 17: 5-10.

81. Chatterjee S, Grosshans H (2009) Active turnover modulates mature microRNA activity in Caenorhabditis elegans. Nature 461: 546-549.

82. Kawasaki H, Taira K (2004) MicroRNA-196 inhibits HOXB8 expression in myeloid differentiation of HL60 cells. Nucleic Acids Symp Ser (Oxf) : 211-212.

83. Mazière P, Enright AJ (2007) Prediction of microRNA targets. Drug Discov Today 12: 452-458.

84. Williams AE (2008) Functional aspects of animal microRNAs. Cell Mol Life Sci 65: 545-562.

85. Eulalio A, Huntzinger E, Nishihara T, Rehwinkel J, Fauser M, et al. (2009) Deadenylation is a widespread effect of miRNA regulation. RNA 15: 21-32.

86. Bazzini AA, Lee MT, Giraldez AJ (2012) Ribosome profiling shows that miR-430 reduces translation before causing mRNA decay in zebrafish. Science 336: 233-237.

87. Hawkins PG, Morris KV (2008) RNA and transcriptional modulation of gene expression. Cell Cycle 7: 602-607.

88. Morozova N, Zinovyev A, Nonne N, Pritchard LL, Gorban AN, et al. (2012) Kinetic signatures of microRNA modes of action. RNA 18: $1635-1655$

89. Lewis BP, Shih IH, Jones-Rhoades MW, Bartel DP, Burge CB (2003) Prediction of mammalian microRNA targets. Cell 115: 787-798.

90. Stark A, Brennecke J, Bushati N, Russell RB, Cohen SM (2005) Animal MicroRNAs confer robustness to gene expression and have a significant impact on 3'UTR evolution. Cell 123: 1133-1146.

91. Li LC (2008) Small RNA-mediated gene activation. In RNA and the Regulation of Gene Expression: A Hidden Layer of Complexity. Casten Academic Press, USA.

92. Place RF, Li LC, Pookot D, Noonan EJ, Dahiya R (2008) MicroRNA-373 induces expression of genes with complementary promoter sequences. Proc Natl Acad Sci U S A 105: 1608-1613.

93. Salmena L, Poliseno L, Tay Y, Kats L, Pandolfi PP (2011) A ceRNA hypothesis: the Rosetta Stone of a hidden RNA language? Cell 146: 353-358.

94. Wheeler BM, Heimberg AM, Moy VN, Sperling EA, Holstein TW, et al. (2009) The deep evolution of metazoan microRNAs. Evol Dev 11: 50-68.
95. Heimberg AM, Sempere LF, Moy VN, Donoghue PC, Peterson KJ (2008) MicroRNAs and the advent of vertebrate morphological complexity. Proc Natl Acad Sci U S A 105: 2946-2950.

96. Peterson KJ, Dietrich MR, McPeek MA (2009) MicroRNAs and metazoan macroevolution: insights into canalization, complexity, and the Cambrian explosion. Bioessays 31: 736-747.

97. Nozawa M, Miura S and Nei M (2010) Origins and evolution of microRNA genes in Drosophila species. Gen Biol Evol 2: 180-189.

98. Caravas J, Friedrich M (2010) Of mites and millipedes: recent progress in resolving the base of the arthropod tree. Bioessays 32: 488-495.

99. Cock JM1, Sterck L, Rouzé P, Scornet D, Allen AE, et al. (2010) The Ectocarpus genome and the independent evolution of multicellularity in brown algae. Nature 465: 617-621.

100. Kozomara A, Griffiths-Jones S (2014) miRBase: annotating high confidence microRNAs using deep sequencing data. Nucleic Acids Res 42: D68-73.

101. Tjaden B, Goodwin SS, Opdyke JA, Guillier M, Fu DX, et al. (2006) Target prediction for small, noncoding RNAs in bacteria. Nucleic Acids Res 34: 2791-2802.

102. Chen CZ, Li L, Lodish HF, Bartel DP (2004) MicroRNAs modulate hematopoietic lineage differentiation. Science 303: 83-86.

103. Miska EA, Alvarez-Saavedra E, Townsend M, Yoshii A, Sestan N, et al. (2004) Microarray analysis of microRNA expression in the developing mammalian brain. Genome Biol 5: R68.

104. Calin GA, Sevignani C, Dumitru CD, Hyslop T, Noch E, et al. (2004) Human microRNA genes are frequently located at fragile sites and genomic regions involved in cancers. Proc Natl Acad Sci U S A 101: 2999-3004.

105. Xu P, Guo M, Hay BA (2004) MicroRNAs and the regulation of cell death. Trends Genet 20: 617-624.

106. Ahmed FE (2007) Role of miRNA in carcinogenesis and biomarker selection: a methodological view. Expert Rev Mol Diagn 7: 569-603.

107. Calin GA, Dumitru CD, Shimizu M, Bichi R, Zupo S, et al. (2002) Frequent deletions and down-regulation of micro- RNA genes miR15 and miR16 at 13q14 in chronic lymphocytic leukemia. Proc Natl Acad Sci U S A 99: 15524-15529.

108. He L, Thomson JM, Hemann MT, Hernando-Monge E, Mu D, et al. (2005) A microRNA polycistron as a potential human oncogene. Nature 435: 828-833.

109. O'Donnell KA, Wentzel EA, Zeller KI, Dang CV, Mendell JT (2005) cMyc-regulated microRNAs modulate E2F1 expression. Nature 435: 839-843.

110. Johnson SM, Grosshans H, Shingara J, Byrom M, Jarvis R, et al. (2005) RAS is regulated by the let-7 microRNA family. Cell 120: 635-647.

111. Iorio MV, Ferracin M, Liu CG, Veronese A, Spizzo R, et al. (2005) MicroRNA gene expression deregulation in human breast cancer. Cancer Res 65: 7065-7070.

112. Gaur A, Jewell DA, Liang Y, Ridzon D, Moore JH, et al. (2007) Characterization of microRNA expression levels and their biological correlates in human cancer cell lines. Cancer Res 67: 2456-2468.

113. Eis PS, Tam W, Sun L, Chadburn A, Li Z, et al. (2005) Accumulation of miR-155 and BIC RNA in human B cell lymphomas. Proc Natl Acad Sci U S A 102: 3627-3632.

114. Brennecke J, Hipfner DR, Stark A, Russell RB, Cohen SM (2003) bantam encodes a developmentally regulated microRNA that controls cell proliferation and regulates the proapoptotic gene hid in Drosophila. Cell 113: 25-36.

115. Chang TC, Wentzel EA, Kent OA, Ramachandran K, Mullendore M, et al. (2007) Transactivation of miR-34a by p53 broadly influences gene expression and promotes apoptosis. Mol Cell 26: 745-752.

116. Calin GA, Croce CM (2006) MicroRNA signatures in human cancers. Nat Rev Cancer 6: 857-866.

117. Blenkiron C, Goldstein LD, Thorne NP, Spiteri I, Chin SF, et al. (2007) MicroRNA expression profiling of human breast cancer identifies new markers of tumor subtype. Genome Biol 8: R214. 
118. DeBakey ME (2009) MicroRNA and colorectal cancer. World J Surg 33: 638-646.

119. Kumar MS, Lu J, Mercer KL, Golub TR, Jacks T (2007) Impaired microRNA processing enhances cellular transformation and tumorigenesis. Nat Genet 39: 673-677.

120. He L, He X, Lim LP, de Stanchina E, Xuan Z, et al. (2007) A microRNA component of the p53 tumour suppressor network. Nature 447: $1130-1134$.

121. Ma L, Teruya-Feldstein J, Weinberg RA (2007) Tumour invasion and metastasis initiated by microRNA-10b in breast cancer. Nature 449 : 682-688.

122. Fabbri M, Calin GA (2010) Epigenetics and miRNAs in human cancer. Adv Genet 70: 87-99.

123. Mayr C, Hemann MT, Bartel DP (2007) Disrupting the pairing between let-7 and Hmga2 enhances oncogenic transformation. Science 315: 1576-1579.

124. Lee YS, Dutta A (2007) The tumor suppressor microRNA let-7 represses the HMGA2 oncogene. Genes Dev 21: 1025-1030.

125. Thomson JM, Newman M, Parker JS, Morin-Kensicki EM, Wright T, et al. (2006) Extensive post-transcriptional regulation of microRNAs and its implications for cancer. Genes Dev 20: 2202-2207.

126. Nielsen BS, Jørgensen S, Fog JU, Søkilde R, Christensen IJ, et al. (2011) High levels of microRNA-21 in the stroma of colorectal cancers predict short disease-free survival in stage II colon cancer patients. Clin Exp Metastasis 28: 27-38.

127. Tang F, Hajkova P, Barton SC, Lao K, Surani MA (2006) MicroRNA expression profiling of single whole embryonic stem cells. Nucleic Acids Res 34: e9.

128. Sassen S, Miska EA, Caldas C (2008) MicroRNA: implications for cancer. Virchows Arch 452: 1-10

129. Hofsli E, Sjursen W, Prestvik WS (2013) Identification of serum microRNA profiles in colon cancer. Br J Cancer 121: 1721-1729.

130. Yang L, Belaguli N, Berger DH (2009) MicroRNA and colorectal cancer. World J Surg 33: 638-646.

131. Bentwich (2005) Prediction and validation of microRNAs and their targets. FEBS Lett 579: 5904-5910.

132. Brennecke J, Stark A, Russell RB, Cohen SM (2005) Principles of microRNA-target recognition. PLoS Biol 3: e85.

133. Rajewsky N, Socci ND (2004) Computational identification of microRNA targets. Dev Biol 267: 529-535.

134. Sethupathy P, Megraw M, Hatzigeorgiou AG (2006) A guide through present computational approaches for the identification of mammalian microRNA targets. Nat Methods 3: 881-886.
135. Cimmino A, Calin GA, Fabbri M, Iorio MV, Ferracin M, et al. (2005) miR-15 and miR-16 induce apoptosis by targeting BCL2. Proc Natl Acad Sci U S A 102: 13944-13949.

136. Matsubara H, Takeuchi T, Nishikawa E, Yanagisawa K, Hayashita Y, et al. (2007) Apoptosis induction by antisense oligonucleotides against miR-17-5p and miR-20a in lung cancers overexpressing miR-17-92. Oncogene 26: 6099-6105.

137. Sylvestre Y, De Guire V, Querido E, Mukhopadhyay UK, Bourdeau V, et al. (2007) An E2F/miR-20a autoregulatory feedback loop. J Biol Chem 282: $2135-2143$.

138. Luo X, Burwinkel B, Tao S, Brenner H (2011) MicroRNA signatures: novel biomarker for colorectal cancer? Cancer Epidemiol Biomarkers Prev 20: 1272-1286.

139. Ein-Dor L, Zuk O, Domany E (2006) Thousands of samples are needed to generate a robust gene list for predicting outcome in cancer. Proc Natl Acad Sci U S A 103: 5923-5928.

140. Graeber TG, Sawyers CL (2005) Cross-species comparisons of cancer signaling. Nat Genet 37: 7-8.

141. Martinez C, Bhattacharya S, Freeman T, Churchman M, Ilyas M (2005) Expression profiling of murine intestinal adenomas reveals early deregulation of multiple matrix metalloproteinase (Mmp) genes. J Pathol 206: 100-110.

142. Senore C, Ederle A, Fantin A, Andreoni B, Bisanti L, et al. (2011) Acceptability and side-effects of colonoscopy and sigmoidoscopy in a screening setting. J Med Screen 18: 128-134.

143. deRoux SJ, Sgarlato A (2012) Upper and lower gastrointestinal endoscopy mortality: the medical examiner's perspective. Forensic Sci Med Pathol 8: 4-12.

144. Rifai N, Gillette MA, Carr SA (2006) Protein biomarker discovery and validation: the long and uncertain path to clinical utility. Nat Biotechnol 24: $971-983$.

145. Chen CZ (2005) MicroRNAs as oncogenes and tumor suppressors. N Engl J Med 353: 1768-1771.

146. Volinia S, Calin GA, Liu CG, Ambs S, Cimmino A, et al. (2006) A microRNA expression signature of human solid tumors defines cancer gene targets. Proc Natl Acad Sci U S A 103: 2257-2261.

147. Saito Y, Liang G, Egger G, Friedman JM, Chuang JC, et al. (2006) Specific activation of microRNA-127 with downregulation of the proto-oncogene BCL6 by chromatin-modifying drugs in human cancer cells. Cancer Cell 9: 435-443. 